\title{
Biosynthetic origin of butyrolactol A, an antifungal polyketide produced by a marine-derived Streptomyces
}

\author{
Enjuro Harunari ${ }^{1}$, Hisayuki Komaki ${ }^{2}$ and Yasuhiro Igarashi ${ }^{* 1}$
}

\author{
Full Research Paper \\ Address: \\ ${ }^{1}$ Biotechnology Research Center and Department of Biotechnology, \\ Toyama Prefectural University, 5180 Kurokawa, Imizu, Toyama \\ 939-0398, Japan and ${ }^{2}$ Biological Resource Center, National Institute \\ of Technology and Evaluation (NBRC), 2-5-8 Kazusakamatari, \\ Kisarazu, Chiba 292-0818, Japan \\ Email: \\ Yasuhiro Igarashi - yas@pu-toyama.ac.jp \\ * Corresponding author \\ Keywords: \\ biosynthesis; butyrolactol; contiguous polyol; hydroxymalonyl-ACP; \\ polyketide; Streptomyces; tert-butyl
}

Beilstein J. Org. Chem. 2017, 13, 441-450.
doi:10.3762/bjoc.13.47

Received: 17 January 2017

Accepted: 20 February 2017

Published: 08 March 2017

This article is part of the Thematic Series "Lipids: fatty acids and derivatives, polyketides and isoprenoids".

Guest Editor: J. S. Dickschat

(c) 2017 Harunari et al.; licensee Beilstein-Institut.

License and terms: see end of document.

\begin{abstract}
Butyrolactol A is an antifungal polyketide of Streptomyces bearing an uncommon tert-butyl starter unit and a polyol system in which eight hydroxy/acyloxy carbons are contiguously connected. Except for its congener butyrolactol B, there exist no structurally related natural products to date. In this study, inspired by our previous genomic analysis, incorporation of ${ }^{13} \mathrm{C}$ - and ${ }^{2} \mathrm{H}$-labeled precursors into butyrolactol A was investigated. Based on the labeling pattern and sequencing analytical data, we confirmed that the tert-butyl group is derived from valine and its $C$-methylation with methionine and the polyol carbons are derived from a glycolysis intermediate, possibly hydroxymalonyl-ACP.
\end{abstract}

\section{Introduction}

Actinomycetes produce structurally diverse secondary metabolites with pharmaceutically useful bioactivities. Importantly, members of the genus Streptomyces have been the main source of drug discovery programs due to their high capacity in secondary metabolism including polyketides, peptides, terpenoids, alkaloids, and amino acid/carbohydrate/nucleic acid derivatives $[1,2]$. One of the largest groups of bacterial secondary metabolites is polyketide from which a range of clinically used drugs have been developed. Polyketides still remain in the focus of drug development because of their structural complexity that can provide attractive templates for new pharmacophores [3]. While the frequency of discovering new skeletons from actinomycetes seems declining, biosynthetic analysis of structurally unique known compounds and the following bioengineering of biosynthetic genes are currently becoming an essential part of the creation of new drug-like structures [4-8].

Butyrolactol A (1) is an antifungal polyketide first isolated from Streptomyces rochei S785-16 [9] (Figure 1). The left half of $\mathbf{1}$ is the hydrophobic unconjugated tetraene system including one 


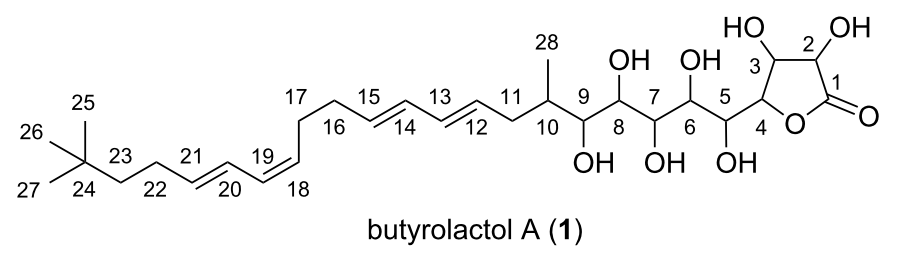

Figure 1: The structure of butyrolactol $A(1)$.

$Z$-olefin with a terminal tert-butyl group, whereas the hydrophilic polyol system bearing a $\gamma$-lactone terminus constitutes the right half of the molecule. To date, no structurally related natural products are known except for its demethyl congener butyrolactol B that was also isolated from the same strain and has an isopropyl group instead of the tert-butyl terminus [9]. Very recently, isolation of butyrolactols $\mathrm{C}$ and $\mathrm{D}$ was presented but the details are not available in public domains [10]. 1 has a broad antimicrobial activity against fungi ranging from Candida albicans to Trichophyton mentagrophytes with comparative activity to nystatin [9]. Despite the uniqueness of the structure and the antifungal potency, no further research has been reported for 1 .

There are two interesting aspects in the structure of butyrolactol A (1). First, among the polyketides, a tert-butyl group has been found exclusively in metabolites of marine cyanobacteria except for 1 [11-14] (Figure 2). Although no experimental evi-<smiles>CCC(C)CC/C=C/N(C)C(=O)C(C)CC(C)CC(=O)OC(CC(C)C)C(C)(C)C</smiles>

laingolide<smiles>CCC(C)CCC(C)C(=O)OC(CC(C)CCC/C=C\C=C/N(C)C(=O)C(C)(C)C)C(C)(C)C</smiles>

madangolide

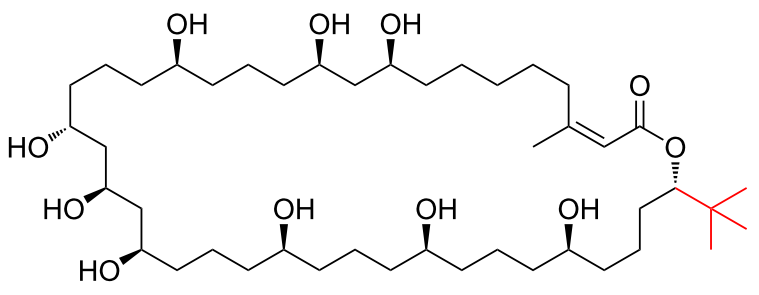

bastimolide $A$

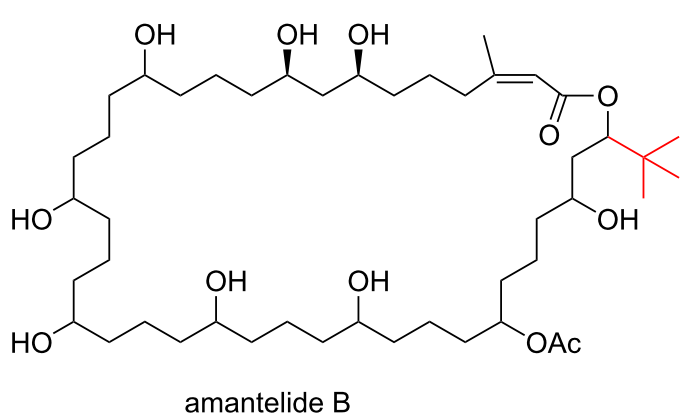<smiles>CC[C@H](C)[C@H](C(=O)N1CCC[C@H]1C(=O)O[C@H](C[C@@H](C)CC(O)[C@@H](C)C1=NC(/C=C(\C)C(=O)N[C@@H](Cc2ccc(OC)cc2)C(=O)N(C)[C@@H](C)C(=O)N(C)C)CS1)C(C)(C)C)C(C)(C)C</smiles><smiles>C=C(CC(=O)N[C@@H](C)C(=O)N(C)C(C(=O)NCC(=O)O)C(C)C)[C@H](C)[C@@H](OC(=O)CN)C(C)=CC(C)=CC(C)(C)C</smiles><smiles>COC(C)CC(C(=O)OC(C=C(C)C(C)C)C(C)C)N(C)C(=O)C(C)N(C)C(=O)CNC(=O)C(NC(=O)C1CCCN1C(=O)[C@H](C)CCC(C)C)C(C)C</smiles>

janadolide 
dence is available, pivaloyl-CoA (2,2-dimethylpropanoyl-CoA) is supposed to be a starter for its biosynthesis [15]. Additionally, trimethylation of malonyl-CoA is proposed for the synthesis of the tert-butyl starter in the biosynthesis of apratoxin A [16]. Another intriguing feature of this molecule is the highly oxygenated carbon chain in which eight hydroxy groups, one of which is used for lactone formation, are contiguously aligned. A 1,3-diol is a common structural element in aliphatic polyketides because the incorporation of malonate-precursors gives rise to the alternative alignment of the methylene and the oxygenated carbons. Meanwhile, a 1,2-diol in polyketides is known to be formed by hydroxylation of methylene carbons as seen in the biosynthesis of erythromycin or amphotericin B [17,18]. The contiguously hydroxylated carbon chain of $\mathbf{1}$ is quite unusual as a polyketide. Examples of similar but shorter polyol carbon chains are ossamycin [19], IB-96212 [20], and antifungalmycin [21], all of which are the secondary metabolites of actinomycetes (Figure 3).

In our investigation on secondary metabolites of marine actinomycetes, butyrolactol A (1) was found to be produced by a Streptomyces strain collected from deep sea water of the Toyama Bay, Japan. In order to get insight into the construction of the above-mentioned unusual structures, we performed an in silico analysis of the biosynthetic genes of $\mathbf{1}$ through draft genome sequencing and proposed its biosynthetic pathway [22]. In this study, biosynthetic precursors of 1 were investigated for further genetic and enzymatic studies.

\section{Results and Discussion}

It was obvious from its structure that $\mathbf{1}$ was synthesized through the malonate pathway. First, $\left[1,2-{ }^{13} \mathrm{C}_{2}\right]$ acetate was fed to the culture to ensure the alignment of malonate units. In the ${ }^{13} \mathrm{C}$ NMR spectrum, split signals arising from ${ }^{13} \mathrm{C}-{ }^{13} \mathrm{C}$ couplings were observed for six pairs of carbons: $\mathrm{C}-11 / \mathrm{C}-12$, C-13/C-14, C-15/C-16, C-17/C-18, C-19/C-20, and C-21/C-22 (Table 1, Figure $\mathrm{S} 1$ in Supporting Information File 1). In the 2D-INADEQUATE spectrum of ${ }^{13} \mathrm{C}$-labeled 1 obtained with a parameter set optimized for ${ }^{1} J_{\mathrm{CC}} 50 \mathrm{~Hz}$, cross peaks derived from the intact ${ }^{13} \mathrm{C}_{2}$ acetate units were detected for the carbon pairs mentioned above (Table 1, Figure 4a).

According to the incorporation result of the doubly labeled acetate, malonyl-CoA is not the extender unit for the lactone (C-1 to C-4) and the pentaol (C-5 to C-9) moieties (Figure 3), suggesting that the contiguous polyol system is not formed by methylene hydroxylation. Another possible pathway for 1,2-diol formation is the incorporation of hydroxymalonyl-ACP from a

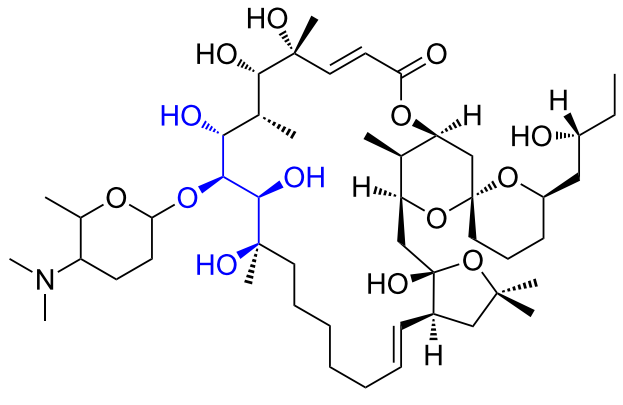

ossamycin<smiles>CCCC(C)C(O)C(O)C(O)C(O)C(O)C(OC1CCC(O)C(C)O1)C(O)C(C)C(O)C(C)C=CC(=O)OC1C(C)C(CCC(C=CC=CCC(C)O)CC(C)C(C)C(O)CC)OC2(CCC(C)C(C(C)C(O)CC)O2)C1C</smiles>

IB-96212<smiles>CCCCCC(O)C(C(=O)OC(C)C(O)C(O)/C=C/C=C/C=C/C=C/C(C)(O)C(O)C(O)C(O)CC(O)CC(O)CC(O)CC(O)CC(O)CC)C(O)C(O)C(O)CCCC</smiles> 


\begin{tabular}{|c|c|c|c|c|c|c|c|}
\hline \multirow[t]{2}{*}{ Position } & \multirow[t]{2}{*}{$\delta_{C}$} & \multicolumn{2}{|c|}{$\left[1,2-{ }^{13} C_{2}\right]$ acetate } & \multicolumn{2}{|c|}{$\left[\mathrm{U}-{ }^{13} \mathrm{C}_{6}\right]$ glucose } & \multirow{2}{*}{$\begin{array}{r}{\left[1-{ }^{13} \mathrm{C}\right] \text { propionate }} \\
\text { relative }\end{array}$} & \multirow{2}{*}{$\begin{array}{l}\mathrm{L}-\left[\text { methyl- }{ }^{13} \mathrm{C}\right] \text { methionine } \\
\text { enrichments }{ }^{\mathrm{a}}\end{array}$} \\
\hline & & $\begin{array}{l}{ }^{1} J_{\mathrm{CC}} \\
(\mathrm{Hz})\end{array}$ & 2D-INADEQUATE & $\begin{array}{l}{ }^{1} J_{\mathrm{CC}} \\
(\mathrm{Hz})\end{array}$ & 2D-INADEQUATE & & \\
\hline 1 & 175.3 & & & 56 & 2 & 0.9 & 0.9 \\
\hline 2 & 74.7 & & & 56 & 1 & 1.0 & 1.0 \\
\hline 3 & 72.9 & & & 39 & 4 & 0.9 & 1.0 \\
\hline 4 & 80.0 & & & 39 & 3 & 1.0 & 1.1 \\
\hline 5 & 66.9 & & & 44 & 6 & 1.0 & 1.0 \\
\hline 6 & 68.9 & & & 44 & 5 & 0.9 & 0.9 \\
\hline 7 & 68.9 & & & 45 & 8 & 1.0 & 1.1 \\
\hline 8 & 69.7 & & & 45 & 7 & 1.0 & 1.1 \\
\hline 9 & 73.1 & & & & & 4.8 & 1.2 \\
\hline 10 & 36.2 & & & & & 1.1 & 1.1 \\
\hline 11 & 36.6 & 41 & 12 & 40 & 12 & 1.2 & 1.2 \\
\hline 12 & 131.9 & 41 & 11 & 40 & 11 & 1.3 & 1.2 \\
\hline 13 & 131.9 & 55 & 14 & 57 & 14 & 1.3 & 1.2 \\
\hline 14 & 131.3 & 55 & 13 & 57 & 13 & 1.2 & 1.0 \\
\hline 15 & 131.3 & 43 & 16 & 43 & 16 & 1.2 & 1.0 \\
\hline 16 & 32.6 & 43 & 15 & 43 & 15 & 1.2 & 1.3 \\
\hline 17 & 27.5 & 42 & 18 & 43 & 18 & 1.4 & 1.3 \\
\hline 18 & 129.2 & 42 & 17 & 43 & 17 & 1.2 & 1.0 \\
\hline 19 & 129.6 & 55 & 20 & 55 & 20 & 1.4 & 1.1 \\
\hline 20 & 125.7 & 55 & 19 & 55 & 19 & 1.3 & 1.1 \\
\hline 21 & 135.9 & 43 & 22 & 43 & 22 & 1.3 & 1.0 \\
\hline 22 & 28.1 & 43 & 21 & 43 & 21 & 1.2 & 1.1 \\
\hline 23 & 43.7 & & & & & 1.6 & 1.2 \\
\hline 24 & 30.6 & & & & & 1.2 & 1.0 \\
\hline 25 & 29.7 & & & & & 0.9 & 7.1 \\
\hline 26 & 29.7 & & & & & 0.9 & 7.1 \\
\hline 27 & 29.7 & & & & & 0.9 & 7.1 \\
\hline 28 & 16.2 & & & & & 1.1 & 1.2 \\
\hline
\end{tabular}

glycolytic intermediate for chain elongation [23]. To investigate this possibility, we conducted a feeding experiment of $\left[\mathrm{U}^{13} \mathrm{C}_{6}\right]$ glucose which could label carbons derived from malonyl-CoA and hydroxymalonyl-ACP. In the ${ }^{13} \mathrm{C}$ NMR spectrum, ${ }^{13} \mathrm{C}-{ }^{13} \mathrm{C}$ couplings were observed for $\mathrm{C}-1 / \mathrm{C}-2, \mathrm{C}-3 / \mathrm{C}-4$, $\mathrm{C}-5 / \mathrm{C}-6, \mathrm{C}-7 / \mathrm{C}-8$ in addition to the carbon pairs $\mathrm{C}-11 / \mathrm{C}-12$, C-13/C-14, C-15/C-16, C-17/C-18, C-19/C-20, and C-21/C-22 (Table 1, Figure S3 in Supporting Information File 1). The 2D-INADEQUATE spectrum showed cross peaks for the above-mentioned two-carbon units derived from the glycolytic degradation of $\left[\mathrm{U}_{-}{ }^{13} \mathrm{C}_{6}\right]$ glucose (Table 1, Figure $4 \mathrm{~b}$ ). Combined with the acetate-labeling result, this labeling pattern suggested that the carbons from $\mathrm{C}-1$ to $\mathrm{C}-8$ are derived from hydroxymalonyl-ACP. This conclusion is supported by the sequencing analysis of the gene cluster for butyrolactol biosynthesis
(Figure 5, Table 2). Four genes coding homologues of enzymes involved in hydroxymalonyl-ACP formation in the zwittermicin biosynthesis ( $\mathrm{ZmaN}, \mathrm{ZmaD}, \mathrm{ZmaG}$, and $\mathrm{ZmaE}$ ) (Figure 6) [24] are present in the downstream of the butyrolactol PKS cluster. Genes coding for $O$-methyltransferase homologues responsible for $O$-methylation of hydroxymalonylACP were not found near the cluster. Hydroxymalonyl-ACP was first identified as an unusual polyketide extender for zittermicin from Bacillus cereus [25]. The occurrence of this uncommon extender unit is limited to some bacterial species Bacillus [25,26], Xenorhabdus [27], Paenibacillus [28], and Streptomyces $[29,30]$.

Methylmalonyl-CoA was readily predicted as the origin of the methyl-branched three-carbon fragment (C-9/C-10/C-28). Actu- 
(a)<smiles>CC(=O)OCCCCCCCCCCCCC=CC=CC(C)C(O)C(O)C(O)C(O)C(O)C1OC(=O)C(O)C1O</smiles>

(b)
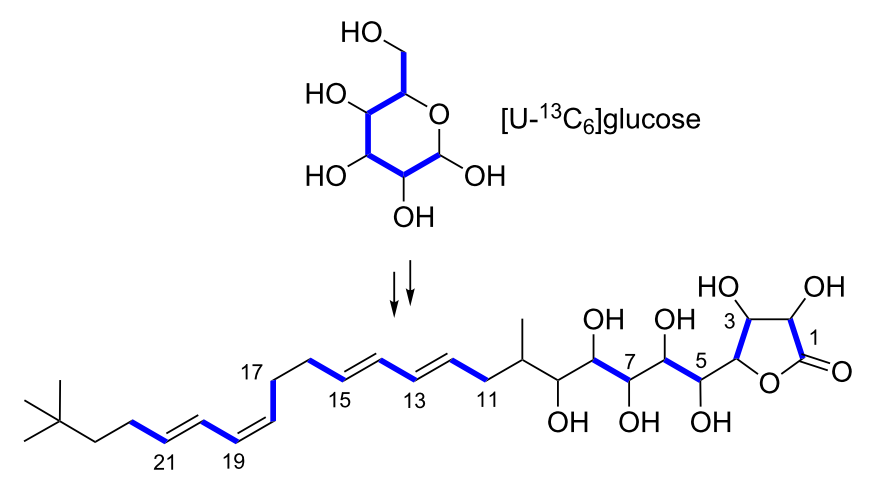
(b) $\left[\mathrm{U}^{13} \mathrm{C}_{6}\right] \mathrm{glucose}$.

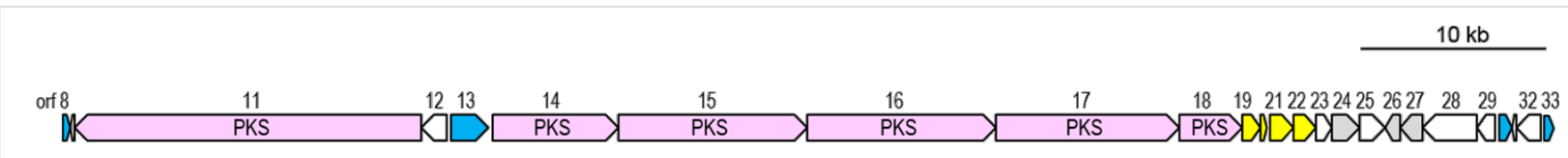

Figure 5: Organization of the biosynthesis gene cluster for 1. Blue, transcriptional regulator; pink, PKS for polyketide backbone of 1; yellow, genes for biosynthesis of hydroxymalonyl-ACP; gray, transporter.

ally, intense enhancement of the C-9 carbon signal was observed by feeding of $\left[1-{ }^{13} \mathrm{C}\right]$ propionate (Table 1$)$. The remaining carbons not labeled by malonate-type precursors were the terminal tert-butyl carbons (C-23 to $\mathrm{C}-27)$. The origin of the tert-butyl group in polyketide biosynthesis is still unknown, however, the tert-butyl functionality of bottromycin and polytheonamide was shown to be produced by radical $C$-methylation of the isopropyl group of valine [31,32]. By analogy, the tert-butyl portion of $\mathbf{1}$ was most likely supplied through the $C$-methylation of valine. To examine this possibility, feeding experiments of $\mathrm{L}-\left[\right.$ methyl $\left.-{ }^{13} \mathrm{C}\right]$ methionine and L-valine- $d_{8}$ were carried out. As expected, the tert-butylmethyl carbons (C-25, C-26, C-27) were labeled as a result of L- $\left[\right.$ methyl $\left.-{ }^{13} \mathrm{C}\right]$ methionine incorporation (Table 1$)$. In addition, the ${ }^{2} \mathrm{H}$ (deuterium) NMR spectrum showed deuterium signals for the methyl group (H-25, H-26, H-27) of L-valine- $d_{8}$-labeled
1 (Figure 7a). The mass spectrum of the L-valine- $d_{8}$-labeled 1 displayed the molecular ion with a mass increment of $6 \mathrm{Da}$ (Figure 7b), corresponding to the incorporation of six deuterium atoms into the terminal methyl groups. Based on these results from precursor-feeding experiments, we concluded that the tertbutyl group and the adjacent methylene carbon $(\mathrm{C}-23)$ are derived from valine and the $S$-methyl carbon of methionine. It is controversial whether pivaloyl CoA is loaded onto the ACP as a starter or isobutyl-CoA is used as a starter and $C$-methylation takes place afterwards. The signature sequence region of the acyltransferase domain of the PKS starter loading module for butyrolactol biosynthesis (FAGHS) shares some amino acid residues with the known loading module of isobutyl CoA (bafilomycin: LAAHS [33], $\alpha$-lipomycin: LAAHS [34], tautomycin: LAAHS [35]). Meanwhile, it is known that the substrate recognition is not strict for the loading module of aver- 


\begin{tabular}{|c|c|c|c|c|c|}
\hline \multirow[t]{2}{*}{ Orf10- } & \multirow[t]{2}{*}{ Accession no. } & \multirow{2}{*}{$\begin{array}{l}\text { Size } \\
(\mathrm{aa})\end{array}$} & \multirow[t]{2}{*}{ Proposed function } & \multicolumn{2}{|l|}{ BLAST search } \\
\hline & & & & Protein homolog, Origin, Accession number & $\%^{a}$ \\
\hline 8 & WP_055469543 & 127 & $\begin{array}{l}\text { HxIR family } \\
\text { transcriptional regulator }\end{array}$ & $\begin{array}{l}\text { HxIR family transcriptional regulator, Streptomyces } \\
\text { sp. NRRL F-7442, KOX41174 }\end{array}$ & $99 / 100$ \\
\hline $10^{\mathrm{b}}$ & WP_030405160 & 71 & $\begin{array}{l}\text { acetyl-CoA carboxylase } \\
\text { biotin carboxyl carrier } \\
\text { protein subunit }\end{array}$ & $\begin{array}{l}\text { acetyl-CoA carboxylase, Streptomyces sp. NRRL } \\
\text { F-7442, KOX41173 }\end{array}$ & $100 / 100$ \\
\hline $11^{\mathrm{b}}$ & WP_055469545 & 6,065 & PKS & FscE, Streptomyces cattleya, AEW99638 & $76 / 82$ \\
\hline $12^{\mathrm{b}}$ & WP_055469546 & 473 & $\begin{array}{l}\text { propionyl-CoA } \\
\text { carboxylase subunit } \\
\text { beta }\end{array}$ & $\begin{array}{l}\text { propionyl-CoA carboxylase subunit beta, } \\
\text { Streptomyces sp. NRRL F-7442, KOX41172 }\end{array}$ & $99 / 99$ \\
\hline 13 & WP_055469547 & 676 & $\begin{array}{l}\text { helix-turn-helix } \\
\text { transcriptional regulator }\end{array}$ & $\begin{array}{l}\text { regulator, Streptomyces sp. NRRL F-7442, } \\
\text { KOX41171 }\end{array}$ & $99 / 99$ \\
\hline 14 & WP_055469666 & 2,075 & PKS & $\begin{array}{l}\text { polyketide synthase type I, Streptomyces cattleya, } \\
\text { AEW } 99622\end{array}$ & $71 / 80$ \\
\hline 15 & WP_055469548 & 3,365 & PKS & FscC, Streptomyces cattleya, AEW99623 & $71 / 79$ \\
\hline 16 & WP_055469549 & 3,462 & PKS & $\begin{array}{l}\text { polyketide synthase (fragment), Streptomyces } \\
\text { cattleya, KOX } 46585\end{array}$ & $99 / 99$ \\
\hline 17 & WP_055469550 & 3,135 & PKS & $\begin{array}{l}\text { polyketide synthase, Streptomyces sp. NRRL } \\
\text { F-7442, KOX46586 }\end{array}$ & $99 / 99$ \\
\hline 18 & WP_055469551 & 1,169 & PKS & $\begin{array}{l}\text { short-chain dehydrogenase, Streptomyces sp. } \\
\text { NRRL-7442, KOX } 46587\end{array}$ & $99 / 99$ \\
\hline 19 & WP_055469552 & 301 & $\begin{array}{l}\text { 3-hydroxyacyl-CoA } \\
\text { dehydratase }\end{array}$ & $\begin{array}{l}\text { 3-hydroxybutyryl-CoA dehydrogenase, } \\
\text { Streptomyces sp. NRRL F-7442, KOX } 46623\end{array}$ & $98 / 99$ \\
\hline 20 & WP_030403675 & 88 & ACP & $\begin{array}{l}\text { Acyl carrier protein, Streptomyces sp. NRRL } \\
\text { F-7442, KOX46588 }\end{array}$ & $100 / 100$ \\
\hline 21 & WP_055469553 & 381 & acyl-CoA dehydratase & $\begin{array}{l}\text { acyl-CoA dehydrogenase, Streptomyces sp. NRRL } \\
\text { F-7442, KOX } 46589\end{array}$ & $99 / 99$ \\
\hline 22 & WP_055469554 & 356 & $\begin{array}{l}\text { glyceroyl-ACP } \\
\text { biosynthesis protein }\end{array}$ & $\begin{array}{l}\text { FkbH, Streptomyces sp. NRRL F-7442, } \\
\text { KOX46590 }\end{array}$ & $99 / 99$ \\
\hline 23 & WP_030403672 & 261 & thioesterase & $\begin{array}{l}\text { thioesterase, Streptomyces sp. NRRL F-7442, } \\
\text { KOX46591 }\end{array}$ & $100 / 100$ \\
\hline 24 & WP_055469555 & 448 & MFS transporter & $\begin{array}{l}\text { major facilitator superfamily permease, } \\
\text { Streptomyces cattleya, AEW99632 }\end{array}$ & $78 / 84$ \\
\hline 25 & WP_055469556 & 408 & hypothetical protein & $\begin{array}{l}\text { uncharacterized protein, Streptomyces sp. NRRL } \\
\text { F-7442, KOX46624 }\end{array}$ & $99 / 100$ \\
\hline $26^{b}$ & WP_055469557 & 253 & $\begin{array}{l}\text { multidrug } \mathrm{ABC} \\
\text { transporter permease }\end{array}$ & $\begin{array}{l}\text { multidrug ABC transporter permease, } \\
\text { Streptomyces sp. NRRL F-7442, KOX46592 }\end{array}$ & $99 / 99$ \\
\hline $27^{\mathrm{b}}$ & $\begin{array}{l}\text { not registered in } \\
\text { GenBank }\end{array}$ & 373 & $\begin{array}{l}\text { ABC transporter } \\
\text { ATP-binding protein }\end{array}$ & $\begin{array}{l}\text { ABC transporter related protein, Streptomyces } \\
\text { cattleya, AEW99635 }\end{array}$ & $82 / 89$ \\
\hline $28^{\mathrm{b}}$ & WP_055469558 & 868 & hypothetical protein & $\begin{array}{l}\text { beta-ketoacyl synthase, Streptomyces sp. NRRL } \\
\text { F-7442, KOX } 46593\end{array}$ & 99/99 \\
\hline $29^{b}$ & WP_055469559 & 290 & ketopantoate reductase & $\begin{array}{l}\text { ketopantoate reductase, Streptomyces sp. NRRL } \\
\text { F-7442, KOX } 46594\end{array}$ & $98 / 99$ \\
\hline 30 & WP_055469560 & 209 & $\begin{array}{l}\text { TetR family } \\
\text { transcriptional regulator }\end{array}$ & $\begin{array}{l}\text { TetR family transcriptional regulator, Streptomyces } \\
\text { sp. NRRL F-7442, KOX46595 }\end{array}$ & $99 / 99$ \\
\hline 31 & WP_059296555 & 65 & chitinase & $\begin{array}{l}\text { secreted chitinase, Streptomyces coelicolor, } \\
\text { NP_733504 }\end{array}$ & $83 / 87$ \\
\hline $32^{b}$ & WP_055469561 & 407 & $\begin{array}{l}\text { FAD-dependent } \\
\text { oxidoreductase }\end{array}$ & $\begin{array}{l}\text { FAD-dependent oxidoreductase, Streptomyces sp. } \\
\text { NRRL F-7442, KOX46596 }\end{array}$ & $98 / 99$ \\
\hline 33 & WP_030403663 & 168 & $\begin{array}{l}\text { MarR family } \\
\text { transcriptional regulator }\end{array}$ & $\begin{array}{l}\text { MarR family transcriptional regulator, } \\
\text { Streptomyces sp. NRRL F-7442, KOX } 46597.1\end{array}$ & $100 / 100$ \\
\hline
\end{tabular}

adentity/similarity; bencoded in complementary strand.

mectin (VPAHS) [36] and myxalamide (VAVHS) [37] which accept both isobutyl-CoA and 2-methylbutyl-CoA. In addition, genes coding for $C$-methyltransferase are not present near the butyrolactol PKS genes. Further enzymatic studies are necessary to establish the order of the starter loading/ $C$-methylation events. 


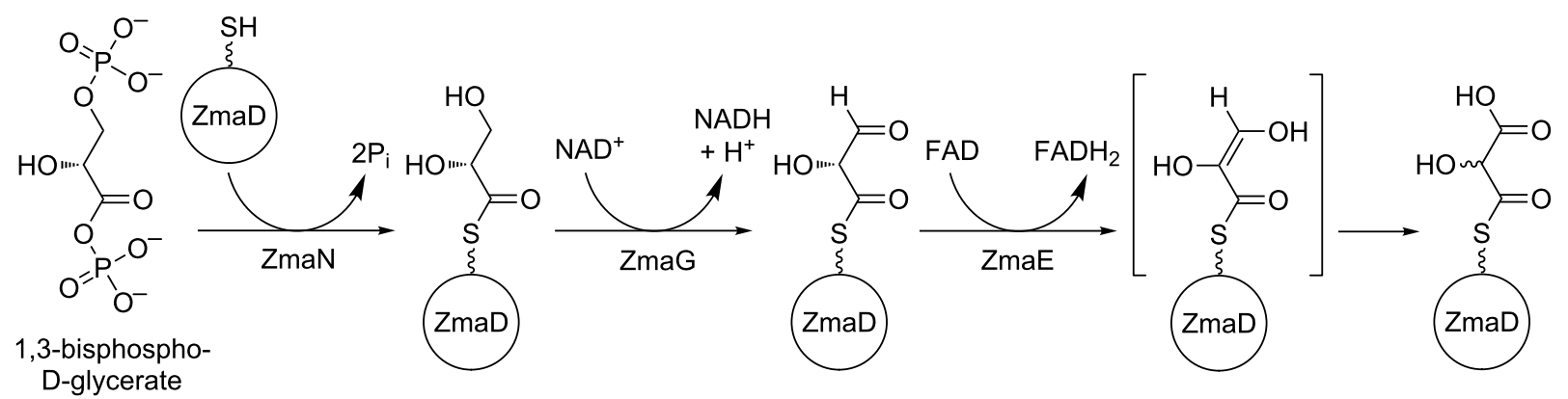

Figure 6: Biosynthetic pathway of hydroxymalonyl-ACP. Adapted from [24].

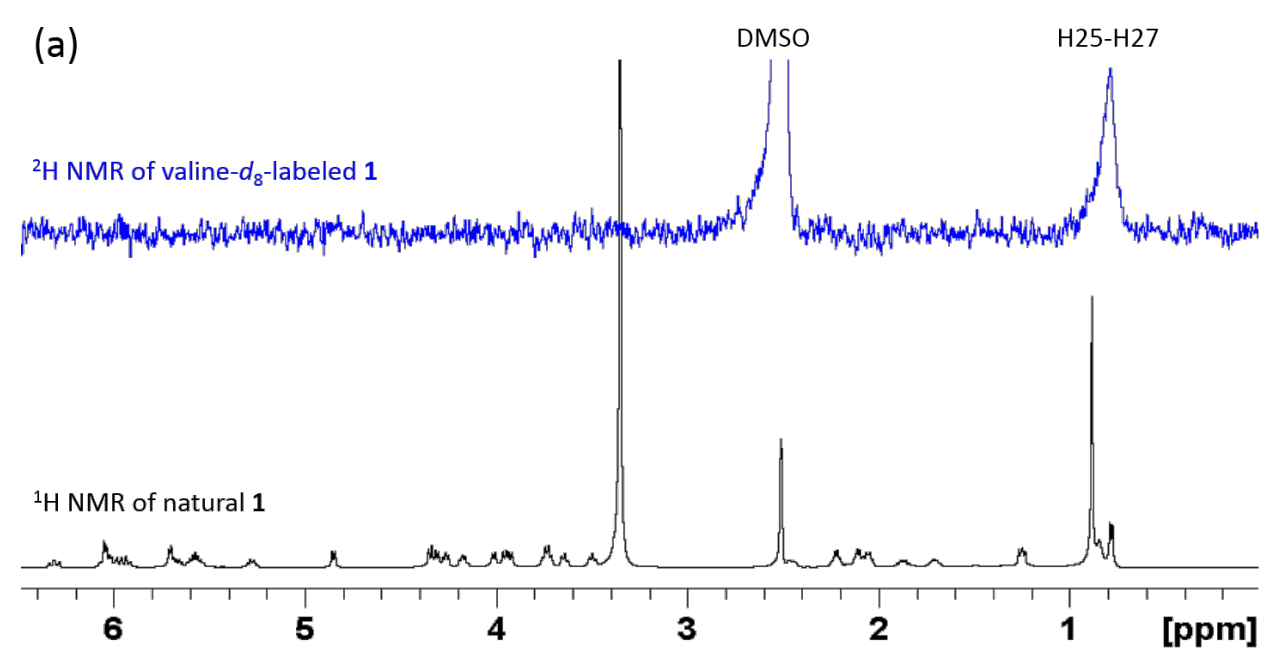

(b)
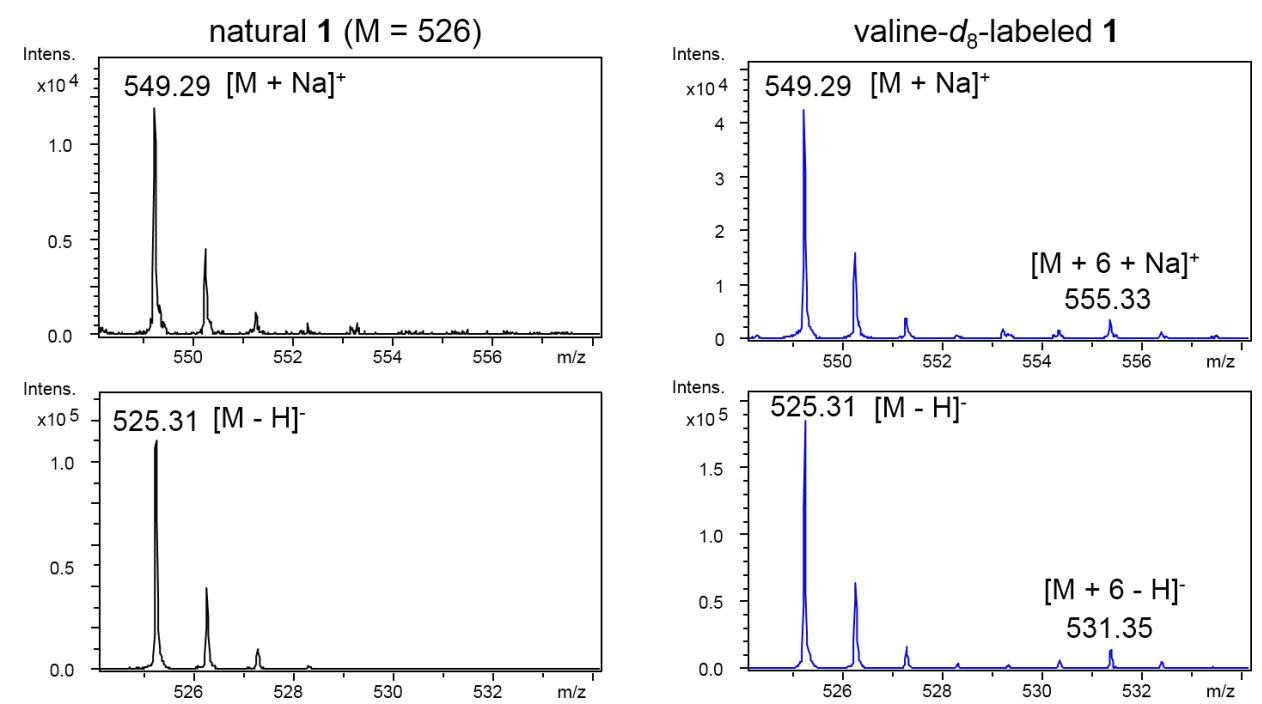

Figure 7: Incorporation of L-valine- $d_{8}$ into 1. (a) ${ }^{1} \mathrm{H}$ NMR spectrum of natural 1 and ${ }^{2} \mathrm{H} N M R$ spectrum of $L$-valine- $d_{8}$-labeled 1 . (b) ESIMS spectra of natural 1 and L-valine- $d_{8}$-labeled 1. 


\section{Conclusion}

In summary, we elucidated the biosynthetic origin of butyrolactol A (1) on the basis of the feeding experiments of isotopelabeled precursors in combination with the bioinformatics analysis of its biosynthetic genes. The overall result of labeling experiments is summarized in Figure 8. The tert-butyl group was shown to be derived from the $C$-methylated isopropyl group of valine. This is the first study that experimentally identified the precursor of a tert-butyl group in a polyketide backbone. The unusual contiguous polyol system comprising eight hydroxylated carbons was proved to be arising from the chain extension using hydroxymalonyl-ACP by labeling experiments of $\left[1,2-{ }^{13} \mathrm{C}_{2}\right]$ acetate and $\left[\mathrm{U}_{-}{ }^{13} \mathrm{C}_{6}\right]$ glucose. This conclusion is consistent with our previous bioinformatic prediction that suggested the presence of genes necessary for the supply of hydroxymalonyl-ACP adjacent to the PKS gene cluster of the butyrolactol biosynthesis. The results obtained in this study provide useful information for further biosynthetic studies and genome mining of structurally unique/novel secondary metabolites.

\section{Experimental}

\section{General experimental procedures}

Sodium $\left[1,2-{ }^{13} \mathrm{C}_{2}\right]$ acetate and L-valine- $d_{8}$ were purchased from Cambridge Isotope Laboratories, Inc. $\left[\mathrm{U}_{-}{ }^{13} \mathrm{C}_{6}\right]$ Glucose, sodium $\left[1-{ }^{13} \mathrm{C}\right]$ propionate, and L- $\left[\right.$ methyl $\left.-{ }^{13} \mathrm{C}\right]$ methionine were purchased from Sigma-Aldrich Co. LLC. ${ }^{1} \mathrm{H}$ and ${ }^{13} \mathrm{C}$ NMR spectra were obtained on a Bruker AVANCE 500 spectrometer in
DMSO- $d_{6}$ using the signal of the residual solvent signals $\left(\delta_{\mathrm{H}} 2.50, \delta_{\mathrm{C}} 40.0\right)$ as an internal standard. The ${ }^{2} \mathrm{H}$ NMR spectrum was obtained on a Bruker AVANCE 500 spectrometer in DMSO. Chemical shifts were referenced to the solvent signal $\left(\delta_{\mathrm{H}(\mathrm{D})} 2.50\right)$. ESITOFMS were recorded on a Bruker microTOF focus.

\section{Microorganism}

Streptomyces sp. strain TP-A0882 was isolated from a deep seawater collected in the Toyama Bay, Japan. The strain was identified as a member of the genus Streptomyces on the basis of $99.9 \%$ 16S rRNA gene sequence identity (1533 nucleotides; NCBI GneBank number BBOK01000029.1) with Streptomyces diastaticus subsp. ardesiacus NRRL B-1773 ${ }^{\mathrm{T}}$ (accession number DQ026631).

\section{Fermentation}

Strain TP-A0882 growing on a plate culture was inoculated into a $500 \mathrm{~mL} \mathrm{~K}-1$ flask containing $100 \mathrm{~mL}$ of the V-22 seed medium consisting of soluble starch $1.0 \%$, glucose $0.5 \%$, NZ-case (Wako Pure Chemical Industries, Ltd.) 0.3\%, yeast extract (Kyokuto Pharmaceutical Industrial Co., Ltd.), 0.2\%, Tryptone (Difco Laboratories) $0.5 \%, \mathrm{~K}_{2} \mathrm{HPO}_{4} 0.1 \%, \mathrm{MgSO}_{4} \cdot 7 \mathrm{H}_{2} \mathrm{O}$ $0.05 \%$, and $\mathrm{CaCO}_{3} 0.3 \%(\mathrm{pH} 7.0$ ). The flask was placed on a rotary shaker $(200 \mathrm{rpm})$ at $30{ }^{\circ} \mathrm{C}$ for 4 days. Then, the seed culture $(3 \mathrm{~mL})$ was transferred into $500 \mathrm{~mL} \mathrm{~K}-1$ flasks each containing $100 \mathrm{~mL}$ of the $\mathrm{A}-3 \mathrm{M}$ production medium consisting of soluble starch $2.0 \%$, glycerol $2.0 \%$, glucose $0.5 \%$, Pharma-

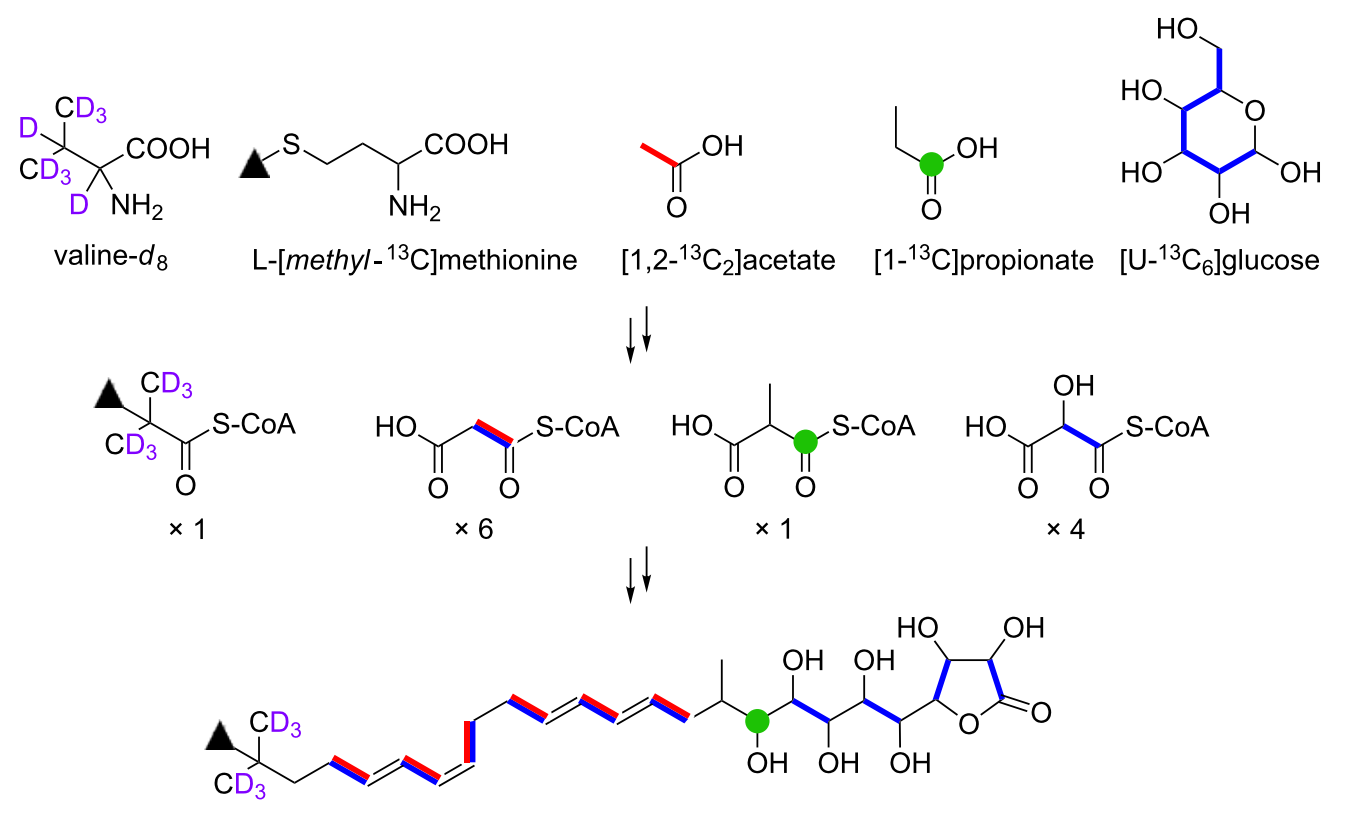

Figure 8: Incorporation of ${ }^{13} \mathrm{C}$ - and ${ }^{2} \mathrm{H}$-labeled precursors into 1 . 
media (Traders Protein) $1.5 \%$, yeast extract $0.3 \%$, and Diaion HP-20 resin (Mitsubishi Chemical Corporation) 1\%. The pH of the medium was adjusted to 7.0 before sterilization. The inoculated flasks were placed on a rotary shaker $(200 \mathrm{rpm})$ at $30^{\circ} \mathrm{C}$ for 6 days.

\section{Extraction and isolation}

After incubation, $100 \mathrm{~mL}$ of 1-butanol was added to each flask, and the flasks were allowed to shake for an hour. The mixture was centrifuged at 6,000 rpm for $10 \mathrm{~min}$ and the organic layer was collected from the aqueous layer. The solvent was removed by evaporation to give $1.6 \mathrm{~g}$ of a crude extract from $1 \mathrm{~L}$ of culture. This crude extract was fractionated using silica gel column chromatography with a step gradient of $\mathrm{CHCl}_{3}-\mathrm{MeOH}$ $(1: 0,20: 1,10: 1,4: 1,2: 1,1: 1$, and $0: 1 \mathrm{v} / \mathrm{v})$. Fraction 4 (4:1) containing 1 was concentrated to give $16.2 \mathrm{mg}$ of dark yellow gum. The final purification was achieved by preparative HPLC (Cosmosil 5C18-AR-II, $10 \times 250 \mathrm{~mm}, 4 \mathrm{~mL} / \mathrm{min}$ ) using a gradient of $\mathrm{MeCN} / 0.1 \% \mathrm{HCO}_{2} \mathrm{H}(\mathrm{MeCN}$ concentration: $50-100 \%$ for $0-30 \mathrm{~min})$ at $4 \mathrm{~mL} / \mathrm{min}$, yielding $\mathbf{1}(2.7 \mathrm{mg})$ with a retention time of $26.7 \mathrm{~min}$.

\section{Incorporation of ${ }^{13} \mathrm{C}$ - and ${ }^{2} \mathrm{H}$-labeled precur- sors}

Feeding experiments were performed for sodium $\left[1,2-{ }^{13} \mathrm{C}_{2}\right]$ acetate, $\left[\mathrm{U}_{-}{ }^{13} \mathrm{C}_{6}\right]$ glucose, sodium $\left[1-{ }^{13} \mathrm{C}\right]$ propionate, $\mathrm{L}-\left[\right.$ methyl- $\left.{ }^{13} \mathrm{C}\right]$ methionine, and L-valine- $d_{8}$. Inoculation, cultivation, and purification were performed in the same manner as described above. Addition of ${ }^{13} \mathrm{C}$ - and ${ }^{2} \mathrm{H}$-labeled precursors was initiated at $48 \mathrm{~h}$ after inoculation and periodically carried out every $24 \mathrm{~h}$ for four times. After further incubation for $24 \mathrm{~h}$, the cultures were extracted with 1-butanol.

1. Sodium $\left[1,2-{ }^{13} \mathrm{C}_{2}\right]$ acetate: After feeding of sodium $\left[1,2-{ }^{13} \mathrm{C}_{2}\right]$ acetate (total $800 \mathrm{mg} ; 20 \mathrm{mg} \times 10$ flasks $\times$ 4 days), $3.6 \mathrm{mg}$ of ${ }^{13} \mathrm{C}$-labeled 1 was obtained from $1 \mathrm{~L}$ of culture.

2. [U- ${ }^{13} \mathrm{C}_{6}$ ]Glucose: After feeding of $\left[\mathrm{U}^{-13} \mathrm{C}_{6}\right]$ glucose (total $800 \mathrm{mg} ; 20 \mathrm{mg} \times 10$ flasks $\times 4$ days), $2.5 \mathrm{mg}$ of ${ }^{13} \mathrm{C}$-labeled 1 was obtained from $1 \mathrm{~L}$ of culture.

3. Sodium $\left[1-{ }^{13} \mathrm{C}\right]$ propionate: After feeding of sodium $\left[1-{ }^{13} \mathrm{C}\right]$ propionate (total $800 \mathrm{mg} ; 20 \mathrm{mg} \times 10$ flasks $\times$ 4 days), $2.1 \mathrm{mg}$ of ${ }^{13} \mathrm{C}$-labeled 1 was obtained from $1 \mathrm{~L}$ of culture.

4. L- $\left[\right.$ Methyl $\left.-{ }^{13} \mathrm{C}\right]$ methionine: After feeding of L-[methyl${ }^{13} \mathrm{C}$ ]methionine (total $80 \mathrm{mg} ; 2.0 \mathrm{mg} \times 10$ flasks $\times$ 4 days), $3.2 \mathrm{mg}$ of ${ }^{13} \mathrm{C}$-labeled 1 was obtained from $1 \mathrm{~L}$ of culture.

5. L-Valine- $d_{8}$ : After feeding of L-valine- $d_{8}$ (total $80 \mathrm{mg}$; $2.0 \mathrm{mg} \times 10$ flasks $\times 4$ days), $2.1 \mathrm{mg}$ of deuterated 1 was obtained from $1 \mathrm{~L}$ of culture.

\section{Supporting Information}

\section{Supporting Information File 1}

NMR spectra of ${ }^{13} \mathrm{C}$ - and ${ }^{2} \mathrm{H}$-labeled $\mathbf{1}$.

[http://www.beilstein-journals.org/bjoc/content/

supplementary/1860-5397-13-47-S1.pdf]

\section{Acknowledgement}

This work was supported by the Japan Society for the Promotion of Science (JSPS) for Young Scientists (15K18692) to E. H. and Institute for Fermentation, Osaka (IFO) for Young Scientists to E. H.

\section{References}

1. Bérdy, J. J. Antibiot. 2005, 58, 1-26. doi:10.1038/ja.2005.1

2. Bérdy, J. J. Antibiot. 2012, 65, 385-395. doi:10.1038/ja.2012.27

3. Hertweck, C. Angew. Chem., Int. Ed. 2009, 48, 4688-4716. doi:10.1002/anie.200806121

4. Sánchez, C.; Méndez, C.; Salas, J. A. J. Ind. Microbiol. Biotechnol. 2006, 33, 560-568. doi:10.1007/s10295-006-0092-5

5. Salas, J. A.; Méndez, C. Trends Microbiol. 2007, 15, 219-232. doi:10.1016/j.tim.2007.03.004

6. Wilkinson, B.; Micklefield, J. Nat. Chem. Biol. 2007, 3, 379-386. doi:10.1038/nchembio.2007.7

7. Kim, W.; Lee, D.; Hong, S. S.; Na, Z.; Shin, J. C.; Roh, S. H.; Wu, C.-Z.; Choi, O.; Lee, K.; Shen, Y.-M.; Paik, S.-G.; Lee, J. J.; Hong, Y.-S. ChemBioChem 2009, 10, 1243-1251. doi:10.1002/cbic.200800763

8. Kong, D.; Lee, M.-J.; Lin, S.; Kim, E.-S. J. Ind. Microbiol. Biotechnol. 2013, 40, 529-543. doi:10.1007/s10295-013-1258-6

9. Kotake, C.; Yamasaki, T.; Moriyama, T.; Shinoda, M.; Komiyama, N.; Furumai, T.; Konishi, M.; Oki, T. J. Antibiot. 1992, 45, 1442-1450. doi:10.7164/antibiotics.45.1442

10. Ko, K.; Ge, H. M.; Shin, J.; Oh, D. C. Planta Med. 2016, 82 (Suppl. Suppl.1), S1-S381. doi:10.1055/s-0036-1596637

11. Dembitsky, V. M. Lipids 2006, 41, 309-340. doi:10.1007/s11745-006-5103-9

12. Shao, C.-L.; Linington, R. G.; Balunas, M. J.; Centeno, A.; Boudreau, P.; Zhang, C.; Engene, N.; Spadafora, C.; Mutka, T. S.; Kyle, D. E.; Gerwick, L.; Wang, C.-Y.; Gerwick, W. H. J. Org. Chem. 2015, 80, 7849-7855. doi:10.1021/acs.joc.5b01264

13. Salvador-Reyes, L. A.; Sneed, J.; Paul, V. J.; Luesch, H. J. Nat. Prod. 2015, 78, 1957-1962. doi:10.1021/acs.jnatprod.5b00293

14. Ogawa, H.; Iwasaki, A.; Sumimoto, S.; Kanamori, Y.; Ohno, O.; Iwatsuki, M.; Ishiyama, A.; Hokari, R.; Otoguro, K.; Omura, S.; Suenaga, K. J. Nat. Prod. 2016, 79, 1862-1866. doi:10.1021/acs.jnatprod.6b00171

15. Mander, L.; Liu, H.-W. Comprehensive Natural Products II: Chemistry and Biology, 1st ed.; Elsevier B.V.: Kidlington, UK, 2010.

16. Grindberg, R. V.; Ishoey, T.; Brinza, D.; Esquenazi, E.; Coates, R. C.; Liu, W.-t.; Gerwick, L.; Dorrestein, P. C.; Pevzner, P.; Lasken, R.; Gerwick, W. H. PLoS One 2011, 6, No. e18565. doi:10.1371/journal.pone.0018565

17. Staunton, J.; Wilkinson, B. Chem. Rev. 1997, 97, 2611-2630. doi:10.1021/cr9600316 
18. Caffrey, P.; Lynch, S.; Flood, E.; Finnan, S.; Oliynyk, M. Cell Chem. Biol. 2001, 8, 713-723.

doi:10.1016/S1074-5521(01)00046-1

19. Kirst, H. A.; Mynderse, J. S.; Martin, J. W.; Baker, P. J.; Paschal, J. W.; Steiner, J. L. R.; Lobkovsky, E.; Clardy, J. J. Antibiot. 1996, 49, 162-167. doi:10.7164/antibiotics.49.162

20. Fernández-Chimeno, R. I.; Cañedo, L.; Espliego, F.; Grávalos, D.; De La Calle, F.; Fernández-Puentes, J. L.; Romero, F. J. Antibiot. 2000, 53, 474-478. doi:10.7164/antibiotics.53.474

21. Wang, Y.-F.; Wei, S.-J.; Zhang, Z.-P.; Zhan, T.-H.; Tu, G.-Q. Nat. Prod. Bioprospect. 2012, 2, 41-45. doi:10.1007/s13659-011-0037-1

22. Komaki, H.; Ichikawa, N.; Hosoyama, A.; Fujita, N.; Igarashi, Y. FEMS Microbiol. Lett. 2015, 362, fnv155. doi:10.1093/femsle/fnv155

23. Chan, Y. A.; Boyne, M. T.; Podevels, A. M.; Klimowicz, A. K.; Handelsman, J.; Kelleher, N. L.; Thomas, M. G. Proc. Natl. Acad. Sci. U. S. A. 2006, 39, 14349-14354. doi:10.1073/pnas.0603748103

24. Park, H.; Kevany, B. M.; Dyer, D. H.; Thomas, M. G.; Forest, K. T. PLoS One 2014, 9, No. e110965. doi:10.1371/journal.pone.0110965

25. Emmert, E. A. B.; Klimowicz, A. K.; Thomas, M. G.; Handelsman, J. Appl. Environ. Microbiol. 2004, 70, 104-113. doi:10.1128/AEM.70.1.104-113.2004

26. Li, Y.; Li, Z.; Yamanaka, K.; Xu, Y.; Zhang, W.; Vlamakis, H.; Kolter, R.; Moore, B. S.; Qian, P.-Y. Sci. Rep. 2015, 5, No. 9383. doi:10.1038/srep09383

27. Park, D.; Ciezki, K.; van der Hoeven, R.; Singh, S.; Reimer, D.; Bode, H. B.; Forst, S. Mol. Microbiol. 2009, 73, 938-949. doi:10.1111/j.1365-2958.2009.06817.x

28. Müller, S.; Garcia-Gonzalez, E.; Genersch, E.; Süssmuth, R. D. Nat. Prod. Rep. 2015, 32, 765-778. doi:10.1039/C4NP00158C

29. Sakuda, S.; Ono, M.; Ikeda, H.; Inagaki, Y.; Nakayama, J.; Suzuki, A.; Isogai, A. Tetrahedron Lett. 1997, 38, 7399-7402. doi:10.1016/S0040-4039(97)01734-6

30. Ono, M.; Sakuda, S.; Ikeda, H.; Furihata, K.; Nakayama, J.; Suzuki, A.; Isogai, A. J. Antibiot. 1998, 51, 1019-1028. doi:10.7164/antibiotics.51.1019

31. Huo, L.; Rachid, S.; Stadler, M.; Wenzel, S. C.; Müller, R. Chem. Biol. 2012, 19, 1278-1287. doi:10.1016/j.chembiol.2012.08.013

32. Parent, A.; Guillot, A.; Benjdia, A.; Chartier, G.; Leprince, J.; Berteau, O. J. Am. Chem. Soc. 2016, 138, 15515-15518. doi:10.1021/jacs.6b06697

33. Hwang, J. Y.; Kim, H. S.; Kim, S. H.; Oh, H. R.; Nam, D. H. AMB Express 2013, 3, No. 24. doi:10.1186/2191-0855-3-24

34. Bihlmaier, C.; Welle, E.; Hofmann, C.; Welzel, K.; Vente, A.; Breitling, E.; Müller, M.; Glaser, S.; Bechthold, A. Antimicrob. Agents Chemother. 2006, 50, 2113-2121. doi:10.1128/AAC.00007-06

35. Zhao, C.; Ju, J.; Christenson, S. D.; Smith, W. C.; Song, D.; Zhou, X.; Shen, B.; Deng, Z. J. Bacteriol. 2006, 188, 4142-4147. doi:10.1128/JB.00173-06

36. Ikeda, H.; Nonomiya, T.; Usami, M.; Ohta, T.; Ōmura, S. Proc. Natl. Acad. Sci. U. S. A. 1999, 96, 9509-9514. doi:10.1073/pnas.96.17.9509

37. Silakowski, B.; Nordsiek, G.; Kunze, B.; Blöcker, H.; Müller, R. Cell Chem. Biol. 2001, 8, 59-69. doi:10.1016/S1074-5521(00)00056-9

\section{License and Terms}

This is an Open Access article under the terms of the Creative Commons Attribution License

(http://creativecommons.org/licenses/by/4.0), which permits unrestricted use, distribution, and reproduction in any medium, provided the original work is properly cited.

The license is subject to the Beilstein Journal of Organic Chemistry terms and conditions:

(http://www.beilstein-journals.org/bjoc)

The definitive version of this article is the electronic one which can be found at:

doi:10.3762/bjoc. 13.47 